\title{
Chapter 16 \\ The Remapping of Forest Governance: From Shareholder to Stakeholder
}

\author{
Roger Hayter and Alex Clapp
}

Resource conflicts are a widespread feature of contemporary globalization, and resource peripheries have become contested battlegrounds that are challenging demands for sustainable development defined in both social and environmental terms (Hayter, Barnes, \& Bradshaw, 2003). As an expression of these contests, in recent decades forest conflicts have proliferated on all continents, in the peripheries of rich and poor countries alike (Gritten, Mola-Yudego, Delgado-Matas, \& Kortelainen, 2012). Not surprisingly, given the highly varied nature of forest ecologies and governance around the world, forest conflicts and approaches to their resolution involve diverse actors and motivations, and they vary considerably in nature (Moran \& Ostrom, 2005). Yet drawing on Westoby's (1989, p. 196) insight, the realization of the non-wood benefits of forests, meaning their environmental and cultural values, has been a significant stimulus underlying forestry conflicts. In this regard, researchers have proposed remapping as an umbrella concept that refers to both a revaluation of forest resources that reforms the dominance of large-scale industrial uses to privilege environmental and cultural priorities, and to implement new land-use plans and forms of governance based on new inventories, resource maps, science, and zoning (Clapp, 2004; Hayter, 2003). In turn, forest remappings are interpreted as part of broader paradigmatic transformations of society and economy that are driven by interacting scientific, technological, cultural, political, and historical forces. In evolutionary terms, contemporary remapping is an attempt to transform the commodity-driven and shareholder-oriented forest management associated with Fordism into more locally diverse forms of governance as part of a post-

Fordist or information and communication techno-economic paradigm

R. Hayter $(\bowtie) \cdot$ A. Clapp

Department of Geography, Simon Fraser University, Burnaby, BC, Canada

e-mail: hayter@sfu.ca; aclapp@sfu.ca 
(Clapp, Hayter, Affolderbach, \& Guzman, 2016). This transformation is not straightforward, but conflict-ridden and contingent.

Researchers have variously defined forest conflicts as disputes over the access and management of resources, as incompatible activities aimed at restricting one another, or as clashes among diverse institutional interests over the control and use of forests as economic, environmental, or cultural resources (Gritten et al., 2012; Hayter et al., 2003). Although these definitions are related, the focus on forest conflicts as institutional clashes captures the sense of remapping as a search for paradigmatic change. In practice, conflicts vary considerably in scope and severity and can, for example, involve minor disputes over (perceived) violation of minor regulations or of inappropriate behavior in the context of existing rules and customs. Agents of conflict-driven remapping, however, specifically seek to fundamentally change existing policies, regulations, "habits of thought" (Veblen, 1899), and the "rules of the game" (North, 1990). In practice, the forces of contemporary remapping are especially evident in peripheries where forest resources have been primarily exploited by corporations for industrial benefits and the forest sector deemed a principal engine of export-led economic growth, such as in British Columbia (BC), Tasmania, and New Zealand (Affolderbach, Clapp, \& Hayter, 2012; Clapp, 2004; Hayter, 2003; Hayter \& Barnes, 2012).

The drivers and direction of contemporary remapping are contentious, caught up in the contesting impulses of neoliberalism and new forms of locally contingent stakeholder governance. On the one hand, Roche (1990) and McCarthy (2006) see neoliberalism as a dominating influence over forest policies in New Zealand and BC respectively, variously expressed in terms of privatization, deregulation, enchantment with MNCs, forest commodification, and more intangibly as a mind-set committed to market solutions. Among poorer countries, Tsing (2005, p. 7) interprets neoliberalism as a "universal" force in constant "friction" with local resource practices. From this perspective, neoliberalist adherents' faith in the priority of market forces to achieve economic efficiencies at the global scale is a powerful impulse in forest peripheries, forming the basis of what we summarily label as a shareholder model or approach to remapping. Yet Roche and McCarthy are highly critical of neoliberal policies and, as implied by Tsing's (2005) friction metaphor in resource peripheries, these policies have been resisted. Indeed, limits to the implementation of neoliberalism have been recognized in large part because of opposition from newly empowered stakeholders and the development of an alternative stakeholder model of governance towards the remapping of forest peripheries (Clapp et al., 2016; Hayter \& Barnes, 2012). In this approach, formerly marginalized actors, such as environmental nongovernmental organizations (ENGOs), indigenous peoples, and other local community actors, become formal stakeholders who gain access to and influence in decision-making processes hitherto dominated by the vested interests of big business and governments. Creators of stakeholder models of governance imply reductions or modifications in the autonomy of both government and business, constraining though not necessarily rejecting market forces to emphasize environmental values and the goals of local communities, including indigenous peoples. Conflicts arise as new stakeholders seek new, often radical definitions, land zones, 
and legal rights to replace entrenched legally defined resource tenures and the commodity values they represent.

In this chapter, we assess the concept of remapping primarily as a transition from shareholder to stakeholder thinking, for positive and normative reasons. Utilizers of the stakeholder model of remapping capture important trends in forest use in rich export-driven peripheries and are closely aligned to the development of what Ostrom (2010, p. 641) labels "polyvalent governance" within common property models derived from experiences in many poor countries (Moran \& Ostrom, 2005). As an ideal type, stakeholders engaged in successful remapping can identify the need for new institutional arrangements and innovations, both to facilitate dialogue among parties in conflict, and to establish durable rules and organizations that enact cooperative forms of sustainable development (Affolderbach et al., 2012; Clapp et al., 2016). In this virtuous cycle, sustainable development generates localized external economies and incorporates public goods and ecosystem services as well as the material values of forests. Such an evolution in resource peripheries may be seen as an extension of Amin and Thrift's (Amin \& Thrift, 1995) institutional thickness, originally conceived to help researchers understand urbanization processes. In contrast, shareholders seeking private sector deregulation produce institutional thinning, while underlining the contentious nature of remapping.

Stakeholder-driven remapping is neither inevitable nor inevitably favorable. Cooperative stakeholder arrangements are necessarily experimental, especially so in peripheral regions whose inhabitants are trying to re-invent themselves. These experiments face uncertainties both political and epistemological, rooted in the nature of bargaining among new and old stakeholders and in new processes of science and learning. The engagement of more stakeholders in turn implies more diverse views and hopes for the future, with the future itself of ambiguous length. Further, institutional thickening may mean more bureaucracy without local development, and institutional thinning may imply the reverse. As Bestor (1998) articulates, the idea of markets is ambiguous, comprising a diverse range of actors and relationships, and if market actors are privileged in shareholder approaches, they also feature as local stakeholders.

Nevertheless, stakeholder and shareholder models are useful contrasting starting points for understanding remappings of resource peripheries with which broader debates over the meaning of globalization can be expressed (Hirst \& Thompson, 1996; Kelly, 1999). Thus, stakeholder-remappings are part of globalizing processes that shift policy making from hierarchical control by governments and markets to more diffuse, democratic forms of governance in which new social forces gain leverage (Bevir, 2012; Jessop, 1998; Mayntz, 2003). In this thinking, if neoliberalism is a global force shaping resource use (Tsing, 2005), so too are the environmental movement (O'Riordan, 2001; Zimmerer, 2006) and the surge in demands for indigenous rights (Mander \& Tauli-Corpuz, 2006), and all feature local adaptations and resistances that interact with one another. Policy formulation is complex and cannot be easily reduced to neoliberal formulations, a view consistent with the theme of the limits of neoliberalism (Hayter \& Barnes, 2012; Johnston \& Glasmeier, 2007; Weller \& O’Neill, 2014). 
We have organized the rest of this chapter into three sections in which we progressively elaborate stakeholder-remapping in its broader societal and policy context, in the natures it produces, and in how it might be evaluated (Fig. 16.1). First, forest remappings are discussed as expressions of socio-economic paradigmatic changes, stimulated by crisis and conflict and in which actors view contemporary remapping as an uncertain policy challenge to the markets and hierarchy governance model of Fordist forestry with its emphasis on commodification. In the second section, we distinguish stakeholder and shareholder impulses in contemporary remapping and elaborate the former by highlighting institutional innovation and thickening in emerging forms of governance. In the last, most speculative section, we explore the meaning of good governance in remapping and how stakeholderremapping may be assessed. We recognize that forest transitions in one form or another are globally widespread (Mather, 1992) and that particular forms of forest conflict, remapping, and conflict resolution are contingent and varied. Although we draw primarily on BC's attempts to remap and resolve forest conflicts, we hope that

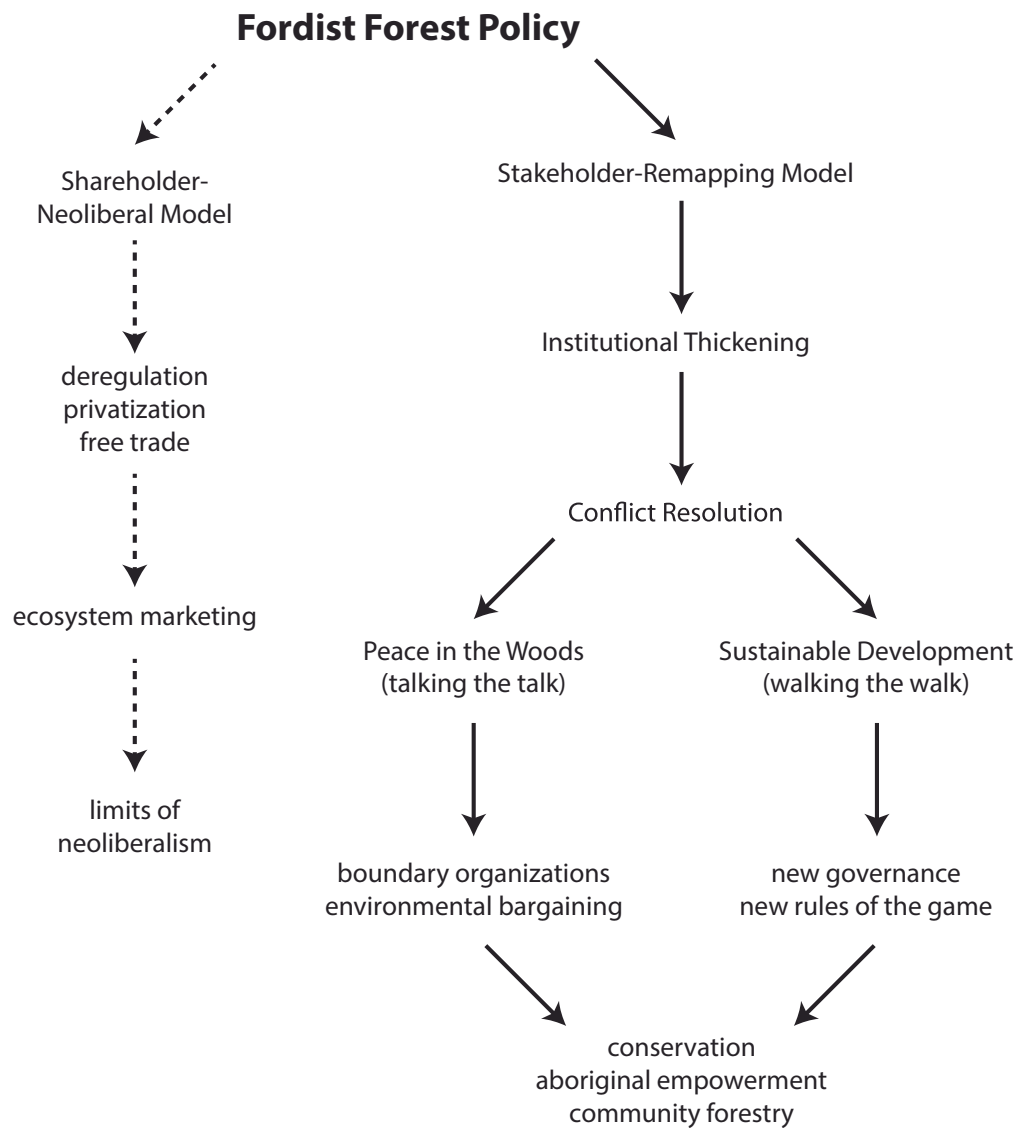

Fig. 16.1 Fordist forest policy. Source: Design by authors 
the discussion will resonate more broadly in other forest regions and to spatially distributed resources in general. Although the latter concern is beyond the scope of this chapter, many key resources coexist in the same peripheries and share in broad outline the challenges posed by changing social values.

\section{Remapping Fordist Forestry as Paradigm Change}

Theorists of economic transformation and paradigmatic change, such as Freeman and Louça (2001), emphasize the role of innovation and root their work in the experience of core countries and leading edge sectors. Similarly, researchers with more spatially sensitive complementary approaches also focus on core regions and agglomerations (Storper, 1997), as do the authors of the original idea of institutional thickness (Amin \& Thrift, 1995). Yet the implications of paradigmatic change for resource peripheries and industries are profound (Hayter, 2000). Indeed, forest policy everywhere is shaped by and evolves in accordance with changing social attitudes and forms of industrialization or innovation-driven paradigms. Reference to paradigmatic change helps illuminate the role of crisis and conflict as catalysts, and the broader evolutionary forces shaping and challenging contemporary remapping.

Drawing on North American experience, three broad forestry remappings can be identified in relation to paradigm changes since the nineteenth century (Clapp et al., 2016; Franklin, Berg, Thornburgh, \& Tappeiner, 1997; Hayes \& Glendenning, 2005). First, nineteenth century industrialization and the rise of largely unfettered market forces heralded an era of deforestation (1850-1910), driven by colonization, dispossession, and speculation, in which old-growth forests, once the common property of indigenous peoples, were remapped as state- or privately-owned resources to facilitate business investment. In tandem with the expansion of the factory system, the scale of forestry and wood-processing activities increased rapidly, stimulated by innovations in steam-powered technology, machinery, and wood pulping, implementers of the latter targeting the coniferous forests of northern regions, including the Pacific Northwest and BC (Rajala, 1998).

Subsequently, policy-makers' searches for more sustainable forest industries and forest-based communities ushered in a second Fordist era of remapping, in accordance with a new "scientific" forestry (1915-1970, peaking after 1945). They based this remapping on sustained yield principles and related silvicultural practices, largely developed in Europe, that supported policies that remained primarily committed to facilitating the industrial use of forests. As part of Fordism's mass production culture, forest sector activities increased in scale, and were linked within newly emerging horizontally and vertically integrated MNCs that owned or controlled vast tracts of forest. Land ownership and large-scale, secure timber tenures were expected to promote sustained yield forest rotations that would allow replacement after harvesting (Hayter, 1976), but the structural incentives for resource depletion were revealed in ambitious and front-loaded timber harvest targets (Clapp, 1995; Marchak, Aycock, \& Herbert, 1999). During Fordism, technological developments 
also enabled the use of hardwoods in pulp and paper, leading to large-scale pine and eucalyptus forest monoculture plantations in Australia, Brazil, Chile, New Zealand, South Africa, the southern United States, and other semi-tropical and warm temperate regions (Clapp, 2001).

Although a central principle, sustained yield proved problematical for industry, while the nonindustrial benefits of forests were also undermined. In response, a third remapping has taken place since 1970, part of what is variously labeled as post-Fordism: the information and communication techno-economic paradigm (ICT), or globalization. Forestry experts suggest that this remapping has been dominated by demands for adaptive, flexible ecosystem-based management aimed at sustainability-ecologically, culturally, and economically. Meanwhile, technological changes featuring micro-electronic technologies have deepened economies of scale and scope in forest product manufacturing.

Environmental opposition to forest commodification has been an important driver of conflict. In Tasmania, for example, as early as 1885, enactors of a pioneering Forest Act explicitly recognized the problem of environmental degradation and created a conservator of forests who subsequently reported forestry practices as "chaotic," even if not much was to change for some time (Carron, 1985; Gee, 2001). In North America, Widick (2009) has documented the rise of environmentallydriven forest conflicts in California since the latter part of the nineteenth century, and Lee and Field (2005) and Langston (2005) in relation to Washington and Oregon, and Wilson (1998) for BC, have documented the role of professionally organized environmental nongovernmental organizations (ENGOs) in challenging prevailing industrial forest practices, especially large-scale clearcutting. The participants of the resulting debates have challenged the scientific wisdom of the Fordist forestry practices that became institutionalized in North America, and whose one-size-fits-all advice "imposed a rational, uniform and simplistic order on the complexities of localized ecological systems" (Lee \& Field, 2005, p. 3). However, as Langston (2005) argues, Fordist sustained yield and silviculture experienced significant problems even for industry. Industrialized forestry practices aimed at maximizing processing efficiencies go hand in hand with a variety of economic risks related to: changes in the species mix to less economically desirable trees, along with the widespread practice of even-aged clear-cutting; increased damage due to disease and insects, fire-proneness, and erosion; and intractable conflicts with other users. Moreover, as mill capacities increased as a result of improvements in efficiency, declining forest productivity associated with the maturation of the resource cycle has led inevitably to the closure of mills, a well-documented trend in Oregon, Washington, and British Columbia (Hayter \& Edenhoffer, 2016; Robbins, 2006).

Remappings resonate beyond western settler societies. Fordist forestry, in one form or another, became widespread, expressed in many developing countries by investments in big, export-oriented, foreign-owned pulp and paper mills, often using plantation wood. In Brazil and Chile, for example, direct foreign investment in the forest sector was a key, often controversial aspect of national development strategies in the 1960s and 1970s (Clapp, 1995; Dauvergne, 1997; Marchak, 1995). Indeed, forest conflicts are globally widespread, and collectively inspire urgent 
pleas for changes in forest governance, typically to better address local development needs simultaneously with promoting environmental sustainability.

\section{Fordist Forestry in British Columbia}

Utilizing an outline of the evolution, nature, and challenge to Fordist forestry in British Columbia (BC), we can better illustrate the general as well as the unique processes of remapping (Hayter, 2000). In BC, consistent with practices across much of Canada, the provincial government has controlled forest resources since joining Confederation in 1871. Although sporadic ventures into industrial forestry had previously occurred, the arrival of the transcontinental railroad in Vancouver in 1885 stimulated a rapid, entrepreneurial-led growth of logging and the forest industries. In support of this growth, the provincial government privatized some forests as railroad land grants and introduced various licenses and leases to permit logging. But forestry became frenzied and speculative, with no concern for renewal, and in response to fears of forest liquidation, the licensing boom was halted in 1905. Following the advice of a Royal Commission established in 1909, the provincial government passed the Forestry Act of 1912 to further limit alienation of forest lands, while retaining the principle of public ownership. Following another Royal Commission, full commitment to Fordism awaited the 1947 Forest Act Amendment. This Amendment and subsequent amendments created large-scale tenures that were offered to corporations, often multinational, over long and renewable time horizons, in exchange for major investments in integrated forest product activities. The tenures were intended to be large enough to allow sustained-yield logging, and a new appurtenancy clause required that timber be processed in local mills to ensure the retention of local employment and a corresponding promotion of development within the province. Essentially, the provincial government sought resource bargains with MNCs to stimulate development and set low rates of stumpage-the fee paid for timber cut-to reflect the costs and uncertainties of exporting commodities from remote areas to distant markets.

For Fordist BC, forest policy was inseparable from industrial policy. With timber valued for its industrial uses alone, old growth forests were routinely classified as decadent or over-mature, calling for rapid harvest before their economic value dropped further from the inexorable advance of heart rot and decay. From an industrial perspective, the particular form of Fordism that developed in BC could be labelled "permeable" (Jenssen, 1989), featuring a high level of foreign ownership, with corresponding profit leakage, reliance on imported technology, and limited development of value-added options. Such truncated development stands in contrast to Scandinavian experience where forest industries remained under domestic control, with multiplier effects captured within the region (Raumolin, 1985). Nevertheless, BC's forest industries boomed after 1945, generating many spin-offs and highincome union employment, while spreading growth throughout the province. Moreover, this growth was relatively stable, and during Fordism average incomes in 
resource communities in BC's periphery were as high if not higher than in the Vancouver metro core (Davis \& Hutton, 1989). Since the 1980s, however, BC's resource communities have experienced considerable instability, labor replacement, and downsizing (Hayter \& Edenhoffer, 2016; Markey, Halseth, \& Manson, 2012).

Fordist forestry in BC started to unravel in the 1970s as growth trajectories leveled off and became more volatile amid a series of increasingly deep recessions, culminating in the severe crisis of the early 1980s. This crisis proved a turning point in the fortunes of the forest industry and in public conceptions of forest governance. The recession exposed the industry's declining competitiveness: Factories had become technologically obsolescent, especially on the coast, and timber supplies had declined in quality and accessibility. In 1981, the government first recognized the onset of the fall-down effect, in which old-growth forests were replaced by lower-yielding second-growth forests, and timber yields per hectare plummeted. Even as industry members began to downsize and restructure, this recession sparked deep-seated and long-lasting "wars in the woods" exacerbated by intersecting environmental, aboriginal, and trade conflicts (Hayter, 2003). ENGOs argued that government and industry were sustaining neither the economy nor the environment, and indigenous groups were alarmed that the forest resource would be downgraded prior to the settlement of their treaty claims. At the same time, a trade war over BC's lumber exports to the US erupted when US sawmillers, also threatened by the recession, believed their problems to be caused by cheap lumber imports from BC, and accordingly sought protection through the creation of the Coalition for Fair Lumber Imports (CFLI). This initiated 35 years of duties, litigation, export restrictions, and managed trade, which continued in newly aggravated form in 2017.

In $\mathrm{BC}$, as elsewhere, economic crisis should not be considered "the" cause of remapping, but rather an important catalytic event occurring as part of longer-run technological, economic, political, and social forces of change. By the 1970s, attitudes across western economies were becoming more pro-environment, whereas established industries were experiencing productivity problems, both trends being evident in BC's forest economy. Furthermore, in contrast to the rest of Canada and other western settler societies, BC's failure to sign treaties with indigenous peoples had long been a source of concern waiting to be sparked. These conflicts empowered environmental and aboriginal interests, not because of a shared view of solutions, but because of their shared opposition to existing forest policy and shareholder entitlements.

\section{Policy Uncertainty}

Anticipating the direction and outcomes of remapping is hard, especially when assessments are made during periods of crisis and conflict. Crisis is important for provoking remapping, as it is for society-wide paradigmatic transformations, because it reveals the need for change, and weakens vested industrial interests through their downsizing, failure, and declining power. At the same time, crisis 
energizes new stakeholders by strengthening their arguments and social legitimacy. Yet successive waves of investment in equipment and infrastructure, managerial know-how and labor skills, and attitudes towards economic growth leave established resource policies and industries deeply ingrained. These forces of inertia are powerful, metaphorically captured by the ideas of the staple trap and the resource cycle; equally challenging is the difficulty of distinguishing short-term or cyclical recessions from secular or turning point recessions in resource sectors in which a history of boom and bust is "normal" and the end of natural abundance is inconceivable. Moreover, cost-reduction strategies in response to immediate survival needs can obscure the need to adapt by investing in R\&D, innovation, and a more skilled workforce from industry members.

Forest conflicts similarly shape the contours of remapping. Widely publicized protests-logging blockades, civil disobedience, market boycott campaigns, disruptions of corporate meetings, and the shaming of environmental culprits-have become symbols of these conflicts. In tandem, litigation has become a vital tool of legitimizing and empowering protest, and of shaping remapping. As Langston (2005, p. 72) argues of forest conflicts in Oregon: "What mattered most about litigation was that it forces a variety of stakeholders, with multiple voices, multiple stories, and multiple perspectives to communicate with each other." Litigation has also been an important tool in promoting aboriginal rights in peripheries, not least in BC, where the Supreme Court of Canada has made several decisions since 1997 that have significantly increased aboriginal control over traditional territories. In Australia and New Zealand, aboriginal rights in resource peripheries have also gained judicial recognition. In the case of Tasmania, where the indigenous population was eliminated, contemporary logging is forbidden wherever artifacts representing the region's aboriginal heritage, such as evidence of stone tools, are present (Hayter \& Barnes, 2012).

Forest conflicts have been generated by newly empowered stakeholders to initiate remapping processes, and their resolution has required new institutions. Indeed, institutional innovation is essential to implement compromises among established and new stakeholders with different motivations and mandates. Such innovation in turn produces new uncertainties and policy dilemmas, rooted in its experimental nature and the range of interests that have to be accommodated. For example, environmental bargaining over forests, especially old growth forests, is inherently difficult because adversaries have fundamentally different views of resource values and no common goal or easy metric to resolve conflicts (Affolderbach, 2011). What might be described as cultural bargaining over aboriginal rights, self-determination, and resource tenure is no less fraught with conflicting value systems. Furthermore, forest policy involves expectations over long-term horizons that are hard to define, can vary among participants, and over the past decade have become more complicated by the implications of climate change, which themselves vary from place to place. In this regard, the ecological implications of sustainable forestry will require increased scientific knowledge of local conditions and ecosystems that can be anticipated to shape forest policy in ways yet unforeseen as they evolve. Faced with these dilemmas, forest remapping is inescapably uncertain. 


\section{Globalization and Forest Conflict Resolution: Shareholder and Stakeholder Models}

The destabilization of Fordism since the late 1970s and the onset of a contemporary, more volatile period of globalization have posed significant policy challenges, stimulating debates about appropriate forms of governance from global to local levels (Jessop, 1998; Mayntz, 2003). These debates have resonated strongly throughout forest peripheries where the models of stakeholder or shareholder remapping provide alternative starting points to remapping (Fig. 16.1). The shareholder model's proponents are allied to neoliberal thinking, emphasizing markets, hierarchies, and the economic motivations of shareholders. In this approach, environmental values can be achieved through privatization and deregulation-that is, by the establishment of appropriate property rights and market exchange rather than by regulation (Anderson \& Leal, 2015). In contrast, the proponents of the stakeholder model of remapping promote more broadly-based decision making driven by new stakeholders, including those committed to principles of sustainability, and whose empowerment comes at the expense of vested market interests and entrenched government and corporate hierarchies. Put another way, the shareholder's share is predominantly, sometimes exclusively, economic, whereas the stakeholder's stake may also be cultural, ethical, environmental, or intrinsic.

In idealized form, shareholder and stakeholder remapping represent different, contentious ideologies and policy prescriptions. Yet these processes are problematic to disentangle and both impulses may exist in the same periphery, both subject to context and contingency. In an Indonesian context, specifically the forest and mining activities of Kalimantan, Tsing (2005) argues that the impact of neoliberalism as a universal force is modified by local frictions in the form of local cultural practices, contributing to hybrid neoliberal forms. At the same time, locally rooted stakeholders typically seek economic development that involves serving markets, and formulators of local plans cannot ignore global connections, whether perceived as threats or opportunities. Further, the environmental and cultural interests underlying new stakeholder models can be seen as either countervailing responses to neoliberalinspired stakeholder remapping or as quasi-autonomous alternatives with distinctive roots and mandates. Indeed, the evolution of environmentalism is intimately linked with industrialization, becoming a powerful expression of contemporary globalization (or universal, in Tsing's terms) in response to the implications of Fordism's rapidly escalating demands for resources in support of mass production and consumption. In turn, environmentalists have sought to impose their views, sometimes against resistance from local peoples who wish to preserve local practices (Stevens, 2014).

As mentioned in our introductory comments, it is tempting to link stakeholder and shareholder approaches respectively with institutional thickening and thinning. In BC's Great Bear Rainforest, for example, stakeholder remapping required institutional innovation and thickening both to bring together opposing parties to exchange views and develop respectful relationships (talking the talk), and to 
implement new forms of governance (walking the walk) that allow actors to use forests in mutually acceptable ways (Clapp et al., 2016). More generally, common property forest tenures around the globe involve cooperation among diverse participants (Moran \& Ostrom, 2005). Ostrom's notion (Ostrom, 2010) of "polyvalent governance" emerges from stakeholder remapping, and with it she underlines the importance of institutional innovation in conflict resolution. In contrast, the privatization of forests in Chile and New Zealand and the reduction in ownership regulations meant the removal of constraints on market-driven interests (Clapp, 1995; Roche, 1990). The blurred distinctiveness of shareholder and stakeholder remapping is captured in the terms themselves: Stakeholder once referred to a miner or logger who had established a stakes for private profit; now it implies participation in more diversified, democratic models of governance.

In practice, remapping is context-driven, shaped by government policies that prioritize development. However, it is often pragmatic, opportunistic, and difficult to categorize, even within the same region. In BC, for example, studies have emphasized neoliberal (shareholder) influences on forest remappings (McCarthy, 2006), the limits and "hybridization" of these influences, and alternative more democratic, shareholder models of governance (Hayter \& Barnes, 2012). This opacity is reflected in broad policy shifts. Thus, during the 1980s, forest policy under a right-wing provincial government became confused, responding effectively to neither the recession nor the wars in the woods. During the 1990s, until 2001, initially under the slogan of bringing "Peace in the Woods," a left-wing government introduced a battery of regulations concerning environmental issues, aboriginal rights, tenure reform, regional planning, and timber taxation that are hard to relate to a neoliberal agenda. Since 2001, right-wing governments have deregulated forestry to some degree, including the removal of appurtenancy, the requirement that logs be processed in local mills. Most recently, in 2017 a new minority left-wing government's attempts to return to a remapping agenda have faced considerable challenges created by continued industry downsizing and concerns for profitability and by the diversity of stakeholder interests. In some respects, stakeholder perspectives have been retained or enhanced, such as in the adoption of the community forest model (McIlveen \& Bradshaw, 2009). Even the controversial removal of appurtenance could be seen as a practical (not ideological) response to declining timber supplies insufficient to support existing mill capacity. In the case of the iconic Great Bear Agreement of 2016, a paradigmatic case of the stakeholder model, although the roots of this accomplishment were established in the left-wing forestry regulation of the 1990s, its realization has occurred under right-wing government since 2001. And if forestry conservation has been a powerful trend in $\mathrm{BC}$, its continuance is not automatic: For example, Tasmania's Nature Conservation Act 2002 is in jeopardy to federal electoral politics (Affolderbach, 2011).

However blurred, the shareholder-stakeholder distinction usefully identifies distinct impulses that can be found, in varying mixes, in forest peripheries around the globe. However, if impulses are defined in terms of strong, sometimes ideological driving or motivating forces, they are not autonomous. Although shareholder thinking is supported by extremely powerful economic and political institutions, 
stakeholder models are increasingly widespread, a trend desirable for enhancing local interests and empowerment in the wise use of resources.

\section{Shareholder Impulses}

The implications of neoliberal imperatives of privatization and deregulation for forest peripheries were most dramatically visible in the burgeoning plantation forest sectors of Chile and New Zealand. Indeed, Chile may be regarded as a neoliberal pioneer, privatizing its plantation forests in the 1970s, predating the emergence of Reaganism and Thatcherism as synonyms for neoliberalism in the 1980s. In practice, however, the expansion of Chile's plantation sector has been heavily subsidized and promoted by government, notably in the $75 \%$ reforestation subsidies established by Decree Law 701 in 1974 (Clapp, 1995). Indeed, the plantations were privatized twice, as the government re-acquired much of the resources following the crisis of the early 1980s, only to then re-auction the plantations and forest lands, in the latter case stimulating a considerable degree of foreign investment. Neoliberalism continues to exert lasting influence in Chile, where ownership of plantations provides collateral and thereby secures access to credit.

In New Zealand's case, in response to economic crisis, the implementers of a new national government's embrace of neoliberalism to provide strategic direction for the economy targeted the forest sector (Roche, 1990). In 1987, the New Zealand Forest Service was replaced by the Forestry Corporation, a state-owned enterprise, that in 1988 began to privatize the country's plantation forests, first established in the 1920s. Privatization, mandated to increase efficiency and reduce the national debt, redefined New Zealand's forest sector. By 1995, over $90 \%$ of plantation forests were under private control, and MNCs became major players controlling more than half of forest production. Nevertheless, New Zealand's policymakers combined their commitment to the neo-liberal shareholder model with a new approach to conservation. The remaining native forests, most located in mountainous regions, were designated for conservation purposes in 1987, and their management turned over to a newly created Department of Conservation. New Zealand's productive plantation forest lands have been leased rather than sold outright, and it remains possible that they could be subject to Maori land claims, even if the latter have been rendered difficult by privatization (Coombes, 2003). Meanwhile in BC, forest lands have remained under public control, and environmental and aboriginal interests have opposed any suggestion of privatization, despite the strong pro-market, neoliberal tendencies routinely associated with right-wing provincial governments. 


\section{Stakeholder Impulses}

In contrast to shareholder thinking, stakeholder impulses to remapping Fordist forestry are driven by diverse motivations, initiatives, and understandings, with priority given to conservation, sustainable development, and stronger commitments to local uniqueness, values, and control. Importantly, the crafters of stakeholder models do not exclude markets, and their evolutionary dynamics are highly varied, predating, coevolving with, and responding to Fordist forestry. In Japan, for example, during the 1950s and 1960s - the heyday of Fordist forestry - small-scale log auctions were expanded throughout the country, reducing transaction costs for local private wood-lot owners and small-scale sawmills (Reiffenstein \& Hayter, 2006). These arrangements, rooted in a long history of cooperative forestry (Totman, 1989), are now in slow decline, because of significant opportunity costs outside of forestry for landowners and workers, coupled with low cost imports. Nevertheless, their continued operation reflects interlinked local concerns for jobs, community, and the environment. In Europe, various forms of small-scale forestry cooperatives exist to similarly maintain the multi-purpose attributes of forests (Weiss, 2011). In many developing countries where communities are highly dependent on forest resources, the actors of various forms of cooperative polyvalent governance manage forests as common property (Ostrom, 2010).

The most visceral conflicts occur where proponents of stakeholder approaches seek to provide an alternative to shareholder models, and to replace implanted Fordist forestry. In these situations, stakeholder models are both more democratic and messier because they diversify and decentralize decision making influence over forest use. Furthermore, the point of a stakeholder model is to demand paradigmatic change in forest use, and to challenge conventional scientific wisdom in forest use that has emphasized the one-size-fits-all approach embodied in the so-called normal forest. In a North American context, for example, Rajala (1998) argues that forestry science evolved as a handmaiden to industry, its scientists privileging the market values of timber and emphasizing a standardized approach to harvesting as well as the rotational clear cutting of large blocks that were expected either to regenerate naturally or by reforestation with a preferred species monoculture. In this view, "over-mature" forests lost value with each year they stood to rot, and needed to be cut quickly, before they became "worthless" (Percy, 1986). However, as previously noted, proponents of this view ignored or under-estimated both environmental and technological risks (Langston, 2005). In contrast, environmental and local proponents of stakeholder models emphasize ecological science aimed at preserving the multiple attributes of forests and their management in locally contingent ways.

Stakeholder remapping of Fordist forestry practices requires the coevolution of learning and bargaining processes among existing vested interests and new stakeholders. In general terms, learners must embrace knowledge of local ecologies and cultural practices and bargaining to embrace actors representing, at least in part, noneconomic interests. In BC's Great Bear Rainforest, for example, institutional innovations enabled the warring parties to talk with one another and exchange views 
in a constructive manner. The Joint Solutions Project (JSP) brought industry members and environmentalists face to face to find common ground, and to develop proposals for stakeholder negotiations. The Coast Information Team (CIT), a scientific boundary organization, and the Turning Point Initiative, a protocol between First Nations and the provincial government, were other crucial institutional innovations that facilitated discussion and bargaining toward the final agreement reached in 2016 (Affolderbach et al., 2012; Clapp et al., 2016; Price, Roburn, \& MacKinnon, 2009). The JSP agreement between industry and ENGOs stopped the latter's market campaigns against the companies in return for a moratorium on logging in 30 watersheds and led to the creation of the CIT. As a boundary organization, the CIT compiled data on the ecology of the GBR in an Ecological Spatial Analysis, a GIS that was constructed by and acceptable to all stakeholders-ENGOs, indigenous peoples, industry, and government (Clapp \& Mortenson, 2011). This organization helped resolve confrontations between ENGOs and industry and encouraged more constructive bargains based on shared knowledge and common areas of agreement. Meanwhile, the Turning Point Initiative depended on recognition by the provincial government that negotiations with indigenous peoples would be "government to government" (G2G), rather than merely stakeholder to government (Davis, 2009). In this regard, a series of court decisions have empowered First Nations, who, from being excluded, have become highly influential, and whose interests, knowledge, and consent must now be explicitly included in forestry decision making.

These institutional process innovations were vital to enable contesting parties to learn and bargain effectively with one another and construct new rules and codes of conduct for the new stakeholder model. Their mission complete in this regard, the JSP and CIT are now disbanded, although the GIS data base remains. Further, as a result of the dialogue inspired by these initiatives, including the G2G negotiations, the final Great Bear Forest Agreement remapped the region in terms of permitted activities and their governance, creating more permanent institutions, in the forms of new rules and organizations-ecosystem-based management, community forests, conservation areas, indigenous forestry firms, and new forms of financing. Will these new developments work out as intended?

\section{Assessing Stakeholder Remapping as an Emergent Form of Good Governance}

Do these new stakeholder agreements that have replaced Fordist forestry models, of the kind illustrated by the GBR Agreement or more ambiguously by Tasmania's Conservation Act, constitute good governance? The answer is not straightforward. As long appreciated, global forest types, uses, and governance are highly differentiated within ecosystems and regions as well as among countries. Nevertheless, the idea of global paradigmatic change comprises possibilities for transformation. Moreover, the idea of a stakeholder model informed by ecological science is rooted 
in the importance of local context. Admittedly, the implications of crisis and conflict for forest governance within stakeholder models may not be important. For example, across Europe, where property rights are well established, institutional innovation in forestry practices is rarely seen as a form of conflict resolution. Elsewhere, however, as Ostrom's (2010) pioneering work has demonstrated for many developing countries, the creation of various forms of polycentric governance has been vital to resolving forest conflicts.

Ostrom (2010, p. 652) systematically analyzed polycentric governance in which problem solving is a major theme and developed a common set of eight "design principles [that promote] long surviving resource institutions" in managing common pool resources.

Locally, the success of stakeholder remapping depends upon the effectiveness of new routines for meeting stakeholder goals for sustained development. These routines are most obviously seen in the establishment of formal organizations and rules, with associated incentives and penalties. Routines and institutions may also be informal and less tangible. Indeed, the authors of a considerable literature suggest that social capital in the form of trust, cooperation and social networking enhances local development (Storper, 1997). From this perspective, brief reference to Ostrom's (2010, p. 652) systematic analysis of polycentric governance as problem solving responses to forestry conflicts around a common set of eight "design principles [that promote] long surviving resource institutions" in managing common pool resources is a good place to begin contemplation of the effectiveness of stakeholder remapping.

As Ostrom argues, polycentric governance encompasses wide-ranging institutional arrangements that are more complex than economic systems controlled by markets and governments. Ostrom's (2010, pp. 653-654) design principles relate to transparency, locally congruent resource appropriation and provision, collective choice arrangements, monitoring of users and resources, sanctions, conflict resolution, recognition of rights, and links to higher levels of governance. Thus, the local resource system should be clearly demarcated, and the boundaries between legitimate users and non-users be defined. Resource appropriation and maintenance rules should make sense in terms of local ecological conditions and the distribution of the benefits and costs of resource utilization should be fair. All stakeholders affected by resource use should be part of the decision making process. Users should monitor resources, and policymakers should graduate sanctions to penalize rule violation and supplement them with low-cost, local mechanisms for conflict resolution. The government should recognize local users' rights to make their own rules. Finally, if part of a larger territory, governance mechanisms are needed to ensure coherence between local and regional decision making. Further, the rules shaping common pool resource use are enormously varied in practice; Ostrom (2010, p. 651), for example, recognizes seven categories of rules pertaining to the role of actors (boundary, position, and choice rules) and potential outcomes (information, aggregation, payoff, and scope rules).

Moreover, in successful polycentric governance design, principles and rules are embedded in social relations in which trust among actors plays a key role (Ostrom, 2010, p. 642). As a central concept of social capital, trust reduces transaction costs 
by facilitating mutual understanding, cooperation, and the predictability of behavior. Indeed, in their analysis of community forestry projects in BC, Mcllveen and Bradshaw (2009) emphasize the strong role of "social cohesion" and "community support" in distinguishing successful projects from failures. Like Markey et al. (2012) in their study of transitioning resource communities in BC, these authors also identified leadership as a key ingredient for local development, but whose availability and capability cannot be guaranteed.

\section{Implications of Conflict Resolution for Trust and Cooperation}

In common pool and property resources, problem solving occurs when disputes arise among users with a shared interest in the resource's use. In Ostrom's design principles, the problems that arise are best handled locally by accepted mechanisms. However, more formidable conflicts arise in the context of remapping when stakeholders have diverse motivations and goals for resource ownership and use and where local, low-profile, and low-cost dispute resolution rules are difficult to construct. Indeed, the effectiveness of agreements rooted in deep-seated conflict and mistrust, and where rule setting is politicized and legalistic, must be questioned in regards to promoting sustainable development. Are the new rules appropriate or even permanent? Will investors face increasing transaction costs? Can stakeholder agreements be modified in the light of experience without generating more rancor and mistrust? Are the new agreements less democratic than messy and cumbersome? Is trust and cooperation possible following protest and litigation?

Although finalized only recently, the Great Bear Rainforest Agreement 2016 helps illuminate the ramifications of these questions. This widely lauded agreement demonstrates the trend from top-down hierarchical and distant decision making over forest resources towards more democratic, locally sensitive governance. In particular, the provincial government and industry have both lost influence, whereas ENGOs and most especially First Nations have gained influence. From a social capital perspective, the GBR Agreement has achieved significant progress in developing cooperation, witnessed by the various forms of institutional thickening as well as the various stakeholders' ability to work together. The Agreement also embraces a wider range of values and privileges local interests who have intimate understanding of local resources and can perhaps be better trusted to achieve sustainable practices.

Yet the main actors involved in the GBR Agreement continue to have different values and conflicting mandates. ENGOs, for example, remain as watchdogs over industrial logging and have already claimed violations of the Agreement by local industry. In contrast, ENGOs are reticent to criticize activities by First Nations, even though they were upset (and surprised) by the latter's decision to reject Forest Stewardship Council certification-the supposed Cadillac standard of ecocertification-because of its costs and bureaucracy. Forest resources for commercial use have been allocated among various indigenous groups who appear to be 
adopting different strategies, ranging from contracting out or hiring specialized companies in ecosystem-based management to hopes of adding value. Whether forest resource allocations are individually large enough to justify investments in processing facilities is an important question, especially if coordination among indigenous groups remains a challenge. Remoteness, difficulties of access, and a small population base mean that both local and export markets are extremely limited.

Within the GBR Agreement, the provincial government reserves the right to approve mining and other resource developments apart from forestry. Any major proposed developments, however, would likely re-ignite opposition and litigation from ENGOs and First Nations who now have the support of recent Canadian Supreme Court precedents. The fear of further litigation is real and in turn indicates higher transaction costs for proposed developments. Beyond perhaps some informal local monitoring and policing by indigenous groups, no locally recognized dispute settlement mechanism seems to exist that can deal with issues expeditiously. Any negotiations for large-scale developments are likely to be messy, at least. Indeed, in stakeholder remapping, such as in the GBR, different interests have distinctive forms of legitimacy, and each group needs to demonstrate some form of achievement to the particular constituencies they serve or wish to address.

From a local development perspective, trust and cooperation are important in developing competitiveness because they reduce the transaction costs of exchange and facilitate the development of localized external economies. Moreover, where human resources are sparse, trust and cooperation are even more important to ensure that available energy is not wasted. But trust and cooperation take time to construct, both informally and formally, and actors must combine them with some form of penalty to prevent opportunism and free riders. From a governance perspective, the failure to develop workable social bargains might well encourage neoliberal impulses in which markets are seen as a more efficient alternative. For local communities and ENGOs, such failure may reinforce conflictual modes of behavior. Even so, from a common property perspective, progress towards clear design principles is evident, for example, in identifying the GBR boundary and the boundaries of ecological sub-regions, the recognition of resource user rights (and benefit streams) among indigenous peoples and principles of local empowerment, and acknowledgement of monitoring functions.

\section{Conclusion}

Forest use and governance is highly varied around the world, engaging societies at all levels of development. Driven by the depletion of old-growth forests, rising population pressures, growing industrial demands for resources, and the globalization of markets, forest conflicts have become widespread. Forest conflicts themselves are highly varied, and may involve: arson, violence, and illegal expropriation, impositions of radically different government policies on local economies, localized disputes among competing users, and the paradigmatic remapping of forest use away 
from a narrow focus on commodity production towards a recognition of environmental and cultural benefits of the forest. In this chapter, we have explored this latter theme.

Remapping is inherently contentious as it involves threats to vested interests and deeply ingrained ideas about resources and development, and it requires alternative patterns of forest use and governance. These proposals have roots in both shareholder and stakeholder models or ways of thinking. If this duality is blurred in practice, we have argued that stakeholder models-akin to Ostrom's concept of polyvalence-potentially provide differentiated, locally informed, and empowering ways to realize the goals of remapping in support of sustainable development. Proponents of shareholder approaches emphasize the public goods and benefits of forests, while recognizing the divergent interests of local and nonlocal actors. Moreover, the creation of stakeholder models on the ground requires innovative thinking, both in terms of bringing divergent parties together and developing new forms of cooperation and trust with new routines and institutions that enact cooperation.

At the same time, stakeholder models need to be validated beyond simple repudiation of shareholder (neoliberal) thinking. That is, stakeholder approaches must be evaluated in terms of their desired goals and mandates. In this regard, future researchers face important challenges. Comparative analyses of the institutional innovations underlying remapping would sharpen understanding of the global-local dynamics shaping initiatives and possibilities regarding new forms of governance. More generally, there is a need to develop frameworks to compare and critically assess whether stakeholder approaches to conflict resolution are working as desired, both in the pioneering regions generating them and in other regions whose inhabitants look to them as models for resource governance. The creators of such frameworks might also incorporate a wider range of resource activities within the theme of remapping, contrasting the spatial footprint and environmental impacts of mining, fishing, and grazing with those of forestry.

\section{References}

Affolderbach, J. (2011). Environmental bargains: Power struggles and decision making over British Columbia's and Tasmania's old-growth forests. Economic Geography, 87, 181-206. https://doi.org/10.1111/j.1944-8287.2011.01107.x

Affolderbach, J., Clapp, R. A., \& Hayter, R. (2012). Environmental bargaining and boundary organizations: Remapping British Columbia's Great Bear Rainforest. Annals of the Association of American Geographers, 102, 1391-1408. https://doi.org/10.1080/00045608.2012.706567

Amin, A., \& Thrift, N. (1995). Globalisation, institutional "thickness" and the local economy. In P. Healey, S. Cameron, S. Davoudi, S. Graham, \& A. Madani-Pour (Eds.), Managing cities: The new urban context (pp. 91-108). Chichester: Wiley.

Anderson, T. L., \& Leal, D. R. (2015). Free market environmentalism for the next generation. New York: Palgrave Macmillan. https://doi.org/10.1057/9781137443397 
Bestor, T. C. (1998). Making things clique: Cartels, coalitions, and institutional structure in the Tskujij wholesale seafood market. In M. Fruin (Ed.), Networks, markets, and the Pacific Rim, Studies in Strategy (pp. 154-80). Oxford, UK: Oxford University Press.

Bevir, M. (2012). Governance: A very short introduction. Oxford, UK: Oxford University Press.

Carron, L. T. (1985). A history of forestry in Australia. Canberra, Australia: Australian National University Press.

Clapp, R. A. (1995). Creating competitive advantage: Forest policy as industrial policy in Chile. Economic Geography, 71, 273-296. https://doi.org/10.2307/144312

Clapp, R. A. (2001). Tree farming and forest conservation in Chile: Do replacement forests leave any originals behind? Society \& Natural Resources, 14, 341-356. https://doi. org/10.1080/08941920119176

Clapp, R. A. (2004). Wilderness ethics and political ecology: Remapping the Great Bear Rainforest. Political Geography, 23, 839-862. https://doi.org/10.1016/j.polgeo.2004.05.012

Clapp, R. A., Hayter, R., Affolderbach, J., \& Guzman, L. (2016). Institutional thickening and innovation: Reflections on the remapping of the Great Bear Rainforest. Transactions of the Institute of British Geographers, 41, 244-257. https://doi.org/10.1111/tran.12119

Clapp, R. A., \& Mortenson, C. (2011). Adversarial science: Conflict resolution and scientific review in British Columbia's central coast. Society \& Natural Resources, 24, 902-916. https:// doi.org/10.1080/08941921003801505

Coombes, B. (2003). The historicity of institutional trust and the alienation of Maori land for catchment control at Mangatu, New Zealand. Environment and History, 9, 333-359. https://doi. org/10.3197/096734003129342872

Dauvergne, P. (1997). Shadows in the forest: Japan and the politics of timber in Southeast Asia. Cambridge, MA: The MIT Press.

Davis, H. C., \& Hutton, T. A. (1989). The two economies of British Columbia. BC Studies, 82, 3-19. https://doi.org/10.14288/bcs.v0i82.1320

Davis, L. (2009). The high stakes of protecting indigenous homelands: Coastal first nations' turning point initiative and environmental groups on the B.C. west coast. International Journal of Canadian Studies, 39, 137-159. https://doi.org/10.7202/040827ar

Franklin, J., Berg, D., Thornburgh, D., \& Tappeiner, J. (1997). Alternative silvicultural approaches to timber harvesting: Variable retention harvest systems. In K. A. Kohm \& J. F. Franklin (Eds.), Creating a forestry for the 21 st century (pp. 111-139). Washington, D.C.: Island.

Freeman, C., \& Louça, F. (2001). As time goes by: From the industrial revolutions to the information revolution. Oxford, UK: Oxford University Press.

Gee, H. (2001). For the forests: A history of the Tasmanian forest campaigns. Hobart: The Wilderness Society.

Gritten, D., Mola-Yudego, B., Delgado-Matas, C., \& Kortelainen, J. (2012). A quantitative review of the representation of forest conflicts across the world: Resource periphery and emerging patterns. Forest Policy and Economics, 33, 11-20. https://doi.org/10.1016/j.forpol.2012.06.008

Hayes, S. P., \& Glendenning, G. (2005). Human values and forests: Changes in the Great Lakes wildlands. In R. G. Lee \& D. R. Field (Eds.), Communities and forests: Where people meet the land (pp. 77-95). Corvallis, OR: Oregon State University Press.

Hayter, R. (1976). Corporate strategies and industrial change in the Canadian forest product industries. Geographical Review, 66, 209-228. https://doi.org/10.2307/213581

Hayter, R. (2000). Flexible crossroads: The restructuring of British Columbia's forest economy. Vancouver, Canada: UBC Press.

Hayter, R. (2003). "The war in the woods": Post-Fordist restructuring, globalization and the contested remapping of British Columbia's forest economy. Annals of the Association of American Geographers, 93, 706-729. https://doi.org/10.1111/1467-8306.9303010

Hayter, R., \& Barnes, T. J. (2012). Neoliberalism and its geographical limits: Comparative reflections from forest peripheries in the global north. Economic Geography, 88, 197-221. https:// doi.org/10.1111/j.1944-8287.2011.01143.x 
Hayter, R., Barnes, T. J., \& Bradshaw, M. J. (2003). Relocating resource peripheries to the core of economic geography's theorizing: Rationale and agenda. Area, 35, 15-23. https://doi. org/10.1111/1475-4762.00106

Hayter, R., \& Edenhoffer, K. (2016). Evolutionary geography of a mature resource sector: Shakeouts and shakeins in British Columbia's forest industries 1980 to 2008. Growth and Change, 47, 497-519. https://doi.org/10.1111/grow.12155

Hirst, P. Q., \& Thompson, G. (1996). Globalization in question: The international economy and possibilities of governance. Cambridge: Polity.

Jenssen, J. (1989). "Different" but not "exceptional": Canada's permeable Fordism. Canadian Review of Sociology and Anthropology, 26, 69-94.

Jessop, B. (1998). The rise of governance and the risks of failure: The case of economic development. International Social Science Journal, 50, 29-45. https://doi.org/10.1111/1468-2451.00107

Johnston, R., \& Glasmeier, A. (2007). Neo-liberalism, democracy and the state: Temporal and spatial constraints to globalization. Space and Polity, 11, 1-23. https://doi. org/10.1080/13562570701406493

Kelly, P. F. (1999). The geographies and politics of globalization. Progress in Human Geography, 23, 379-400. https://doi.org/10.1177/030913259902300303

Langston, N. (2005). Resource management as a democratic process: Adaptive management on federal lands. In R. G. Lee \& D. R. Field (Eds.), Communities and forests: Where people meet the land (pp. 52-76). Corvallis, OR: Oregon State University.

Lee, R. G., \& Field, D. R. (2005). Introduction: From scientific forestry to community forestry. In R. G. Lee \& D. R. Field (Eds.), Communities and forests: Where people meet the land (pp. 1-14). Corvallis, OR: Oregon State University.

Mander, J., \& Tauli-Corpuz, V. (2006). Paradigm wars: Indigenous peoples' resistance to globalization. San Francisco: Sierra Club.

Marchak, M. P. (1995). Logging the globe. Montreal, Canada: McGill-Queens University Press.

Marchak, P., Aycock, S., \& Herbert, D. (1999). Falldown: Forest policy in British Columbia. Vancouver: David Suzuki Foundation and Ecotrust.

Markey, S., Halseth, G., \& Manson, D. (2012). Investing in place: Economic renewal in northern British Columbia. Vancouver, Canada: UBC Press.

Mather, A. S. (1992). The forest transition. Area, 24, 367-379. Retrieved from https://www.jstor. org/stable/20003181

Mayntz, R. (2003). Governing failures of the problem of governability: Some comments on a theoretical paradigm. In J. Kooiman (Ed.), Modern governance: New government-society interactions (pp. 9-20). London: SAGE.

McCarthy, J. (2006). Neoliberalism and the policy of alternatives: Community forestry in British Columbia and the United States. Annals of the Association of American Geographers, 96, 84-104. https://doi.org/10.1111/j.1467-8306.2006.00500.x

McIlveen, K., \& Bradshaw, B. (2009). Community forestry in British Columbia, Canada: The role of local community support and participation. Local Environment, 14, 193-205. https://doi. org/10.1080/13549830802522087

Moran, E. F., \& Ostrom, E. (2005). Seeing the forest and the trees: Human-environment interactions in forest ecosystems. Cambridge, MA: The MIT Press.

North, D. C. (1990). Institutions, institutional change and economic performance. Cambridge, UK: Cambridge University Press.

O'Riordan, T. (2001). Globalism, localism and identity: Fresh perspectives on the transition to sustainability. London: Earthscan.

Ostrom, E. (2010). Beyond markets and states: Polycentric governance of complex economic systems. American Economic Review, 100, 641-672. https://doi.org/10.1257/aer.100.3.641

Percy, M. (1986). Forest management and economic growth in British Columbia. Ottawa: Economic Council of Canada, Supply and Services. 
Price, K., Roburn, A., \& MacKinnon, A. (2009). Ecosystem-based management in the Great Bear Rainforest. Forest Ecology and Management, 258, 495-503. https://doi.org/10.1016/j. foreco.2008.10.010

Rajala, R. A. (1998). Clearcutting the Pacific rain forest: Production, science and regulation. Vancouver, Canada: UBC Press.

Raumolin, J. (1985). The impact of forest sector on economic development in Finland and Eastern Canada. Fennia, 163, 395-437.

Reiffenstein, T., \& Hayter, R. (2006). Domestic timber auctions and flexibly specialized forestry in Japan. The Canadian Geographer, 50, 503-525. https://doi. org/10.1111/j.1541-0064.2006.00160.x

Robbins, W. G. (2006). Hard times in paradise. Seattle, WA: University of Washington.

Roche, M. M. (1990). Perspectives on the post-1984 restructuring of state forestry in New Zealand. Environment and Planning A, 22, 941-999. https://doi.org/10.1068/a220941

Stevens, S. (2014). Indigenous peoples, national parks, and protected areas: A new paradigm linking conservation, culture, and rights. Tuscon, AZ: University of Arizona Press.

Storper, M. C. (1997). The regional world: Territorial development in a global economy. New York: Guilford.

Totman, C. D. (1989). The green archipelago: Forestry in preindustrial Japan. Berkeley, CA: University of California Press.

Tsing, A. L. (2005). Friction: An ethnography of global connection. Princeton, NJ: Princeton University Press.

Veblen, T. (1899). The theory of the leisure class: An economic study of institutions. New York: Macmillan.

Weiss, G. (2011). The study of innovation in the forest sector: Relevance and research background. In G. Weiss, D. Pettenella, P. Ollonqvist, \& B. Slee (Eds.), Innovation in forestry: Territorial and value chain relationships (pp. 1-9). Wallingford: CABI. https://doi. org/10.1079/9781845936891.0000

Weller, S., \& O'Neill, P. (2014). An argument with neoliberalism: Australia's place in a global imaginary. Dialogues in Human Geography, 42, 105-130. https://doi. org/10.1177/2043820614536334

Westoby, J. C. (1989). Introduction to world forestry: People and their trees. Oxford: Basil Blackwell.

Widick, R. (2009). Trouble in the forest: California's redwood timber wars. Minneapolis, MN: University of Minneapolis Press.

Wilson, J. (1998). Talk and log: Wilderness politics in British Columbia. Vancouver, Canada: UBC Press.

Zimmerer, K. S. (Ed.). (2006). Globalization and new geographies of conservation. Chicago, IL: University of Chicago.

Open Access This chapter is licensed under the terms of the Creative Commons Attribution 4.0 International License (http://creativecommons.org/licenses/by/4.0/), which permits use, sharing, adaptation, distribution and reproduction in any medium or format, as long as you give appropriate credit to the original author(s) and the source, provide a link to the Creative Commons license and indicate if changes were made.

The images or other third party material in this chapter are included in the chapter's Creative Commons license, unless indicated otherwise in a credit line to the material. If material is not included in the chapter's Creative Commons license and your intended use is not permitted by statutory regulation or exceeds the permitted use, you will need to obtain permission directly from the copyright holder.

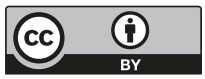

